\title{
Legitimate and necessary: adjudicating human rights violations related to activities causing environmental harm or risk
}

\author{
Dinah Shelton \\ Manatt/Ahn Professor of International Law, the George Washington University Law School, USA
}

The UN International Law Commission and various scholars have devoted attention in recent years to the issue of the so-called fragmentation of international law. Far less consideration has been given to the proliferation, if not fragmentation, of international jurisdictions. Cross-regime issues, such as disputes concerning both labour conditions and trade, or investment and environmental regulation, pose problems because the mandates of specialized tribunals generally call for preferential, if not exclusive, application of the specific area of law for which the bodies were created. Despite this, the legitimacy of tribunals deciding matters within their jurisdiction is generally accepted, even if disputes sometimes arise over the appropriate choice of law or about how to reconcile competing interests such as between trade law and environmental protection. It is therefore somewhat puzzling to encounter questions about whether it is legitimate for human rights courts to decide human rights cases involving violations related to underlying environmental conditions or activities posing risk of environmental harm. This article examines some explanations for this situation, and concludes that it is both legitimate and necessary for human rights tribunals to hear human rights complaints notwithstanding the fact that complaints originate in environmental conditions or activities posing a risk of environmental harm with negative impacts on human well-being.

Keywords: fragmentation, international jurisdictions, human rights violations, environmental harm, environmental risk

The UN International Law Commission and various scholars have devoted attention in recent years to the issue of the so-called fragmentation of international law. ${ }^{1}$ Far less consideration has been given to the proliferation, if not fragmentation, of international jurisdictions. ${ }^{2}$ The international community created its first tribunals at the end of the

1. See Conclusions of the work of the Study Group on the Fragmentation of International Law: Difficulties arising from the Diversification and Expansion of International Law (2006), adopted by the International Law Commission at its Fifty-Eighth session, in 2006, A/61/10, para 251; Yearbook of the International Law Commission, 2006, vol. II, Part Two.

2. For general discussions of international tribunals, see RB Bilder, International Dispute Settlement and the Role of Adjudication (Institute of Legal Studies 1986) 47-49; JE Noyes, 'The Third-Party Dispute Settlement Provisions of the 1982 United Nations Convention on the Law of the Sea: Implications for States Parties and for Nonparties', in MH Nordquist and JN Moore (eds), Entry into Force of the Law of the Sea Convention (Martinus Nijhoff 1995) 213; Sir R Jennings, 'The Role of the International Court of Justice in the Development of International Environment Protection Law' (1992) 1 RECIEL 240-44; PC Jessup, 'Do New Problems Need New Courts?' (1971) 65 Proceedings of the American Society of International Law 261-68; M Lachs, 'Some Reflections on the Settlement of International Disputes' (1974) 
nineteenth century with the establishment of the Permanent Court of Arbitration (PCA) and the short-lived Central American Court of Justice (1907-1918), followed later by the Permanent Court of International Justice (PCIJ), predecessor to the current International Court of Justice (ICJ). In recent decades, the two existing tribunals of general jurisdiction, the PCA and ICJ, have been complemented by a wide variety of specialized bodies given competence over criminal law, trade law, investment law, administrative law, law of the sea and human rights law. A striking exception to this list is international environmental law, a subject area which nonetheless may arise in matters before other international tribunals.

Indeed, the growing number of international tribunals means litigants may have a choice of forums with jurisdiction over their dispute. Even within a single subject area, like human rights, a complaint about discrimination in wages or other conditions of employment, for example, may fall within the competence of the International Labour Organization, UNESCO, UN treaty bodies such as the Committee on the Elimination of Discrimination against Women, Human Rights Committee and Committee on the Elimination of Racial Discrimination, as well as one or more regional tribunals. Cross-regime issues, such as disputes concerning both labour conditions and trade, or investment and environmental regulation, pose particular problems because the mandates of specialized tribunals generally call for preferential, if not exclusive application of the specific area of law for which the bodies were created; thus, for example, human rights tribunals enforce human rights law and the WTO dispute settlement bodies apply trade law. The tribunals will thus differ in their focus and priorities among legal norms, although accepted rules of treaty interpretation call for taking into consideration all relevant international law. ${ }^{3}$

The legitimacy of tribunals deciding matters within their jurisdiction is generally accepted, even if disputes sometimes arise over the appropriate choice of law or about how to reconcile competing interests such as between trade law and environmental protection. It is therefore somewhat puzzling to encounter questions about whether it is legitimate for human rights courts to decide human rights cases involving violations related to underlying environmental conditions or activities posing risk of environmental harm. This article speculates that the reasons could be similar to those that have blocked the creation of specialized tribunals for the environment ${ }^{4}$ and have also caused resistance to adding express guarantees of a safe and healthy environment to global and regional human rights instruments. Such concerns may also account for the backlash that followed some decisions of human rights tribunals

68 Proceedings of the American Society of International Law 323-31. See also PC Jessup, 'Do New Problems Need New Courts?' in MK Nawaz (ed), Essays on International Law in Honor of Krishna Rao (Indian Society of International Law/Thomson Press (India) 1976) 206-213.

3. The Vienna Convention on the Law of Treaties, Art 31(3)(c) provides that a treaty shall be interpreted taking into account 'Any relevant rules of international law applicable in the relations between the parties'. Vienna Convention on the Law of Treaties, 22 May 1969, 1155 U.N.T.S. 331, 8 I.L.M. 679. For an example of the incorporation and use of a broad range of international norms by human rights tribunals, see Demir and Baykara $v$ Turkey, ECtHR Application no 34503/97, judgment of 12 Nov 2008 (GC).

4. Efforts to upgrade the status of the United Nations Environment Program (UNEP) and expand its mandate have been pursued unsuccessfully at least since 1992, as have attempts to establish an International Court of the Environment; see O Pederson, 'An International Environmental Court and International Legalism' (2012) 24 J Environmental Law 547-558; Amedeo Postiglione ICEF <http://www.uncsd2012.org/content/documents/120icef.pdf>; see also $<$ http://icecoalition.com>. 
calling for precautionary measures in cases related to economic development projects and environmental harm. The article nonetheless concludes that it is both legitimate and necessary for human rights tribunals to hear human rights complaints notwithstanding the fact that complaints originate in environmental conditions or activities posing a risk of environmental harm with negative impacts on human well-being.

\section{THE ABSENCE OF ENVIRONMENTAL TRIBUNALS}

One important justification for litigating environmentally-based cases in human rights tribunals is that there are few alternatives once domestic remedies have been exhausted. Despite the efforts of activists and NGOs, States have shown considerable resistance to creating environmental monitoring and enforcement bodies. The Aarhus Compliance Committee ${ }^{5}$ and the petition procedure of the NAFTA Commission for Environmental Cooperation ${ }^{6}$ are often cited as exceptions, but they are, in substance, enforcing the human rights of information, public participation and access to justice, albeit in regard to environmental matters at national level, and aim to ensure the rule of law by insisting that Member States enforce the environmental laws they have freely adopted. They are not generally enforcing international environmental law.

Several factors could explain States' reluctance to create litigation-based compliance mechanisms in the field of international environmental law. First, the scope of State obligations in respect to the environment may be vastly expanded in time and space, compared to other international obligations. Environmental texts often refer to the rights or interests of future generations, recognizing that a degraded and depleted environment harms not only present generations, but future generations of humanity as well. ${ }^{7}$ Tribunals tasked with enforcing international environmental law would likely have to consider intergenerational equity in matters presented to them,

5. The Committee functions pursuant to the UNECE Convention on Access to Information, Public Participation in Decision-making and Access to Justice in Environmental Matters (Aarhus Convention), 25 June 1998, 2161 UNTS 447; 38 ILM 517 (1999).

6. Canada, Mexico and the United States adopted the North American Agreement on Environmental Cooperation (NAAEC) as a side agreement to the North American Free Trade Agreement (NAFTA), 32 ILM 289, 605 (1993). NAAEC allows members of the North American public to submit a complaint that a NAAEC country is failing effectively to enforce its environmental law. Information about the submissions and the process are available at $<\mathrm{http}: / / \mathrm{www}$. cec.org/>.

7. Eg 'fauna constitute a natural heritage of aesthetic, scientific, cultural, recreational, economic and intrinsic value that needs to be preserved and handed on to future generations'. Convention on the Conservation of European Wildlife and Natural Habitats, Sept. 19, 1979, pmbl. Europ. TS No 104. The following also mention future generations: Convention Concerning the Protection of the World Cultural and Natural Heritage (1972), 1037 UNTS 151 (World Heritage Convention), Article 4; UN Framework Convention on Climate Change (1992), 1771 UNTS 107 (UNFCCC), Preamble and Article 3(1); Convention on Biological Diversity (1992), 1760 UNTS 79 (CBD), Preamble and Article 2; Rio Declaration on Environment and Development (1992), UN Doc A/CONF 151/26/REV 1, 31 ILM 874 (Rio Declaration), Principles 3 and 21; Reference could also be made here to P Lawrence, Justice for Future Generations: Climate Change and International Law (Edward Elgar 2014). 
in gauging whether or not the State in question had breached its international obligations. $^{8}$

Even more problematic, especially in the light of global climate change, is the potentially unlimited territorial scope of State obligations. Human rights instruments generally require each state to respect and ensure guaranteed rights 'to all individuals within its territory and subject to its jurisdiction'. 9 This geographic limitation reflects the assumption that a State normally will have the power to protect or the possibility to violate the human rights only of those within its territory and jurisdiction, absent exceptional circumstances. In reality, a State polluting its coastal waters or atmosphere may cause significant harm to individuals and the environment thousands of miles away. States emitting high levels of greenhouse gases or depleting their forests or other carbon sinks can contribute to climate change that threatens the global environment. As with intergenerational equity, the geographic extent and substantive scope of State responsibility for environmental harm abroad would need to be considered by any environmental tribunal.

A further factor inhibiting the creation of environmental tribunals may be the fact that most environmental harm is directly caused by private actors and not by actions of the State or its agents. State responsibility is usually based instead on the State's failure to act with due diligence to prevent or to remedy injury for acts by private entities under its control, often but not always in violation of domestic law. When the law itself is deficient from an environmental perspective, this may be a deliberate choice of the State in choosing to give priority to short-term economic gain and development projects seen to benefit the State as a whole, even if particular communities must bear a disproportionate burden as a result. Also significant is the availability of the ICJ, although it created a never-used and now-suspended environmental chamber. ${ }^{10}$

Potential access to the ICJ may give rise to a conviction that a specialized environmental tribunal is unnecessary, at least for transboundary environmental harm. ${ }^{11}$ Furthermore, most governments, even if they have not had to respond to a complaint, are very likely to be aware of the numerous cases of human rights violations caused by environmental conditions that have been brought before human rights tribunals, as is further discussed below.

8. The invocation of the rights of future generations has already occurred in national courts. See, eg the Philippine judgment of Minors Oposa v Secretary of the Department of Environment and Natural Resources, Supreme Court of the Philippines, 33 ILM 173 (1994) and the extensive jurisprudence of the courts of India. See also Lawrence (n 7).

9. International Covenant on Civil and Political Rights (1966) 999 UNTS 171 (ICCPR), Art 2(1). The European Court of Human Rights has several times indicated that jurisdiction in international law is 'primarily territorial'. Bankovic and Others $v$ Belgium and Others, ECtHR, Application No 52207/99 (admissibility dec. 12 Dec. 2001) (GC), para 59; Issa and Others $v$ Turkey, ECtHR Application No 31821/96, 16 Nov 2004.

10. See <http://www.icj-cij.org/court/index.php?p1=1\&p2=4> accessed 12 May 2015.

11. Transnational pollution and other environmental harm has been central to a considerable number of recent and older ICJ cases: Case Concerning the Gabcikovo-Nagymaros Project (Hungary v Slovakia), 1997 ICJ Rep 7 (25 Sept); Pulp Mills on the River Uruguay (Argentina v Uruguay) 2010 ICJ Rep 14 (20 Apr); Aerial Herbicide Spraying (Ecuador v Colombia), removed from the list 13 Sept. 2013, Press Release 2013/20; Whaling in the Antarctic (Australia v Japan; New Zealand intervening), ICJ judgment 31 March 2014, as well as the earlier Advisory Opinion on the Threat or Use of Nuclear Weapons, 1996 ICJ Rep 226 (8 July). 
As a consequence of these or other factors, most environmental protection treaties are not implemented through liability regimes or invocation of State responsibility, ${ }^{12}$ but rather through various incentive or trade-off mechanisms and State reporting. In contrast, human rights treaties not only rely upon State reporting procedures, but also inter-State complaints, and individual petitions or complaints, all of which directly or indirectly permit criticism of non-complying States. Despite the reluctance of some States to create international environmental monitoring bodies or tribunals, ${ }^{13}$ this article submits that human rights cases based on environmental harm are appropriately, even necessarily, brought before human rights tribunals, while environmental litigation per se is not generally presented or adjudicated by human rights bodies and thus is left to the mechanisms created by environmental agreements and general international law. ${ }^{14}$

\section{HUMAN RIGHTS BODIES HEAR HUMAN RIGHTS CASES}

Human rights tribunals are created by and have jurisdiction in respect of a specific treaty or treaties, wherein the relevant rights and obligations are set forth and indications given of the norms that the tribunal may apply. ${ }^{15}$ These human rights bodies are created expressly 'to ensure the observance of the engagements undertaken by the High Contracting Parties' ${ }^{16}$ or to 'have competence with respect to matters relating to the fulfilment of the commitments made by the States Parties' to the agreement. ${ }^{17}$ The language of these mandates indicates that States Parties intend the tribunals to undertake compliance monitoring of State obligations. They do so even when the underlying cause of the violation lies in environmental conditions. In general, these are pollution matters, rather than conflicts over depletion of natural resources. In other words, these cases are mostly about what human activities are injecting into the biosphere, not what they are taking out. The exception to this is found in cases concerning the ancestral lands of indigenous peoples, where collective property rights extend to the use of natural resources on and sometimes under those lands. ${ }^{18}$

12. For a discussion of the limited recourse to state responsibility in environmental law, see AC Kiss and D Shelton, International Environmental Law (3rd edn, Transnational 1996), 6, 221, 348-60.

13. It should be noted, however, that there is a growth in national environmental courts and tribunals, especially in Asia; see GW Pring and C Pring, Greening Justice: Creating and Improving Environmental Courts and Tribunals (Access Initiative 2009).

14. The duty of States not to create or allow significant transboundary environmental harm is recognized now as part of the corpus of general international law. See, in particular, the ICJ judgments and advisory opinions cited above (n 11). See also, Declaration of the United Nations Conference on the Human Environment (1972), UN Doc A/Conf.48/14/Rev 1(1973) (Stockholm Declaration), Principle 21 and Rio Declaration (n 7) Principle 2.

15. In some instances, human rights treaties give the commission or court an expansive list of normative sources they may apply in interpreting the guaranteed human rights. See, eg African Charter on Human and Peoples' Rights (1981), OAU Doc CAB/LEG/67/3 rev 5, 21 ILM 58 (ACHPR), Arts 60, 61; American Convention on Human Rights (1969), OAS Treaty Series No 36, 1114 UNTS 123 (ACHR), Art 29.

16. European Convention for the Protection of Human Rights and Fundamental Freedoms (1950), ETS 5,213 UNTS 221 (ECHR), Art 17.

17. ACHR (n 15), Art 33.

18. See, eg Mayagna (Sumo) Awas Tingni Community v Nicaragua (Merits, Reparations and Costs), Judgement IACtHR (Ser C) No 79, (31 August 2001); Maya Indigenous 
In general, procedural human rights linked to environmental protection receive more attention than do substantive environmental rights in legal instruments, ${ }^{19}$ jurisprudence, ${ }^{20}$ and in doctrine. ${ }^{21}$ Yet, it is unwise to place confidence in the decisionmaking process alone, as is illustrated by Zander $v$ Sweden, ${ }^{22}$ wherein the applicants complained about contamination of their well water by cyanide from a neighbouring waste disposal site. The municipality initially furnished temporary water supplies, but later, adhering to the normal regulatory procedures, the town raised the permissible level of cyanide in the city water supply, further contaminating the well water. The permit for the dump was later renewed and expanded, while the applicant's request for safe drinking water was denied.

Apart from the African Commission and Court on Human and Peoples' Rights, no international human rights tribunal monitors compliance with a treaty-based 'right to environment' provision, because no such right was written into UN human rights treaties, the European Convention on Human Rights $(\mathrm{ECHR})^{23}$ or the American Convention on

Communities of the Toledo Dist $v$ Belize, Case 12.053, IACommHR, Report No 40/04, OEA/ Ser.L/V/II.122 doc 5, rev 1; Yakye Axa v Paraguay (Merits, Reparations and Costs), 17 June 2005, Ser C, No 125; Case of the Moiwana Community (Suriname) (2005), IACtHR (Ser C) no 124, para 131; Sawhoyamaxa Indigenous Community v Paraguay, IACtHR (Ser C) No 146 (2006); Xakmok Kasek Indigenous Community v Paraguay, 214 IACtHR (Ser C) (2010); Kichwa Indigenous Peoples of Sarayaku v Ecuador, 245 IACtHR (Ser C) (27 June 2012). For treaty rights of indigenous people related to the environment, see ILO, Convention Concerning Indigenous and Tribal Peoples in Independent Countries (ILO Doc 169), adopted 27 June 1989, entered into force 5 September 1991, 28 ILM 1382. Although there is no global treaty on indigenous rights, the General Assembly did adopt the 2007 UN Declaration on Rights of Indigenous Peoples A/RES/61/295; see in particular the Preamble, Arts 29(1) and 32(3).

19. Most environmental agreements now contain provisions calling for public information and participation. See, eg Convention on Civil Liability for Damage Resulting from Activities Dangerous to the Environment (Lugano, 21 June 1993), Arts 13-16; North-American Agreement on Environmental Co-operation (13 September 1993), Art 2(1)(a); International Convention to Combat Desertification in those Countries Experiencing Serious Drought and/or Desertification, particularly in Africa (Paris, 17 June 1994), Preamble, Arts 10(2)(e), 13(1) (b), 14(2), 19 and 25; Convention on Co-operation and Sustainable Use of the Danube River (Sofia, 29 June 1994), Art 14; Protocol on Water and Health to the 1992 Convention on the Protection and use of Transboundary Watercourses and International Lakes (London, 17 June 1999), Art 5(i); Cartagena Protocol on Biosafety to the Convention on Biological Diversity (Montreal, 29 January 2000), Art 23.

20. See, eg Apirana Mahuika et al. v New Zealand, Comm No 547/1992, CCPR/C/70/D/547/ 1993, views issued 16 Nov 2000, in which the Human Rights Committee found no violation of Maori fishing rights, emphasizing that they had the opportunity to participate in the decisionmaking process relating to the fishing measures adopted.

21. See, eg S Atapattu, 'The Right to a Healthy Life or the Right to Die Polluted? The Emergence of a Human Right to a Healthy Environment Under International Law' (2002) 16 Tul Envtll L J 65, 72-73.

22. Zander v Sweden, App No 14282/88, ECtHR [1993] Ser A, No 279B. Zander's claim before the European Court was partially successful. The Court, finding that the applicants had a right to clean water under Swedish law, held that the lack of judicial review violated the Article 6(1) ECHR because the applicants were entitled as of right to seek precautionary measures against water pollution.

23. ECHR (n 16). 
Human Rights (ACHR). ${ }^{24}$ This alone may give rise to State objections that human rights tribunals are exceeding their jurisdiction in deciding cases related to the environment, but in fact UN treaty bodies and the Inter-American and European tribunals most often hear complaints about failures to enforce national environmental rights ${ }^{25}$ or about environmental degradation that violates one or more of the guaranteed rights in the agreements over which they have jurisdiction. ${ }^{26}$ In other words, human rights tribunals hear human rights cases - they do not hear environmental cases.

\section{HUMAN RIGHTS AND ENVIRONMENT CASES FOCUS ON THE RULE OF LAW}

The cases presented in Europe and the Americas are often centred on issues of the rule of law because they are grounded in the failure of States to enforce their own constitutions, laws and judicial decisions. ${ }^{27}$ These cases raise quintessential human rights issues. Taşkin and Others $v$ Turkey, ${ }^{28}$ for example, involved challenges to the development and operation of a gold mine, which the applicants alleged caused environmental damage to the detriment of people in the region. Applicants litigated the issue and won at all levels of the domestic courts. The Turkish Supreme Administrative Court repeatedly concluded that the operating permit in issue did not serve the public interest and that the safety measures that the company had taken did not suffice to eliminate the risks involved in such an activity. Yet, the Prime Minister refused to comply with the court decisions and intervened to prevent closure of the mine. Before the European Court of Human Rights (ECtHR), the applicants alleged a violation of Articles 2, 6(1), 8 and 13 ECHR. Given the failure to enforce the domestic law and the appropriate international standards, the ECtHR rightly found violations of Articles 6 (1) and 8, also holding that it was unnecessary to address the other rights invoked.

The issue of compliance with domestic law is particularly important when there is a domestic constitutional right to environmental protection. Okyay and Others $v$ Turkey ${ }^{29}$ concerned the failure of Turkish authorities to enforce constitutional rights and statutory environmental laws. The applicants had successfully challenged in domestic courts the operations of thermal-power plants in Southwest Turkey, which they claimed would damage the environment and pose risks for the life and health of

24. ACHR (n 15). The Additional Protocol to the American Convention on Human Rights in the Area of Economic, Social and Cultural Rights (1988), OASTS No 69, 28 ILM 161 (Protocol of San Salvador) does contain environmental rights in Art 17, but the article was not made justiciable.

25. In many of the cases discussed above the applicants cite constitutional provisions guaranteeing the right to a safe and healthy or other quality environment. See, eg Okyay v Turkey, App. No. 36220/97, ECtHR Reports of Judgments and Decisions [hereinafter Reports] 2005-VII (12 July), 43 EHRR 788 (2006) and Kyrtatos v Greece, app. No. 4666/98, Reports 2003-VI (22 May) (extracts), discussed above.

26. Most commonly invoked are the rights to life, health, property, culture, information, privacy and home life. See D Shelton, 'Developing Substantive Environmental Rights' (2010) 1 JHRE 89-121.

27. The ECtHR requires at a minimum that the State should have complied with its domestic environmental standards. See, eg Ashworth and Others $v$ the United Kingdom, App. No. 39561/ 98, 20 Jan. 2004; Moreno Gomes v Spain, 2004-X Eur. Ct. H.R. 327 (2005).

28. Taşkin and Others v Turkey, App. No. 46117/99, 2004 Eur. Ct. Hum.Rts. 621 (10 Nov.).

29. Okyay and Others $v$ Turkey (n 25), 57. 
the Aegean region's population and their right to live in a healthy and balanced environment. They did not argue that they had suffered any economic or other loss. The ECtHR agreed that they had a right under Turkish law to protection against damage to the environment and that their rights under Article 6(1) ECHR had been violated due to the failure of Turkish authorities to comply in practice and within a reasonable time with the domestic court's judgments.

Tatar $v$ Romania ${ }^{30}$ arose in the aftermath of an ecological disaster at a Romanian gold mine that resulted in high levels of sodium cyanide and heavy metals being released into local freshwaters. In its judgment finding violations, the ECtHR made note of the right to a healthy and balanced environment in the Romanian Constitution and of the domestic law implementing this right.

Noise pollution cases often turn on compliance with local environmental laws. Where the state conducts inspections and finds that the activities do not exceed permissible noise levels established for the area, at least in the absence of evidence of serious and long-term health problems, the Court is unlikely to find that the State failed to take reasonable measures to ensure the enjoyment of Article 8 rights. ${ }^{31}$ In other words, where no specific environmental quality is guaranteed by the constitution or by an applicable human rights instrument, the Court accords considerable deference to the level of environmental protection enacted by State or local authorities, applying a broad version of its doctrine of 'margin of appreciation'. ${ }^{32}$

Domestic constitutional guarantees and other enactments are most important in cases where the applicants have no independent claim under the European Convention for severe pollution, but instead are seeking nature protection or protection of the environment more generally. In Kyrtatos $v$ Greece, ${ }^{33}$ as in the Okyay case, the applicants' claim involved a constitutional provision protecting the environment. In domestic courts, the applicants and the Greek Society for the Protection of the Environment and Cultural Heritage asserted that the local prefect's decisions to allow development projects, and consequently disputed building permits, were illegal because the area concerned was a swamp safeguarded by Article 24 of the Greek Constitution, which protects the environment. The domestic court held that the prefect had violated Article 24 of the Constitution, because the decision put in jeopardy an important natural habitat for various protected species, including birds, fishes and sea-turtles. It followed that the building permits were also unlawful and had to be quashed. The decision was not enforced by the local authorities, who instead issued further building permits. Given the constitutional provision, the European Court found a violation of Article 6(1), because the domestic law gave environmental rights to the applicants and the government had failed to enforce them.

Like the European Court, the Inter-American Commission and Court of Human Rights (IACommHR and IACtHR) have held that each government must enforce the laws that it enacts as well as any constitutional guarantee of a particular quality of environment. ${ }^{34}$ The IACommHR is clear: 'Where the right to life, to health and

30. Tatar v Romania, App. No. 67021/01, 27 Jan 2009.

31. See, eg Leon and Agnieszka Kania v Poland, App No 12605/03, 21 July 2009, para 102; Borysewicz v Poland, App No 71146/01, 1 July 2008, para 55.

32. See, eg Hatton and Others $v$ the United Kingdom, (GC) App. no. 36022/97, Reports 2003-VIII.

33. Kyrtatos v Greece (n 25).

34. Within the OAS, numerous Member State constitutions contain environmental rights. The domestic law of Ecuador, for example, recognizes the relationship between the rights to life, 
to live in a healthy environment is already protected by law, the Convention requires that the law be effectively applied and enforced'. ${ }^{35}$ The Commission has conceded that the right to development implies for each state the freedom to exploit its natural resources, including through the granting of concessions and acceptance of international investment. Nonetheless, States are not exempt from human rights obligations in their development projects: 'the absence of regulation, inappropriate regulation, or a lack of supervision in the application of extant norms may create serious problems with respect to the environment which translate into violations of human rights protected by the American Convention'. ${ }^{36}$

Human rights tribunals also insist that States comply with international law applicable to them. The European Court's Tatar judgment ${ }^{37}$ focused in large part on the procedural rights to information, public participation and redress, but it also considered the substantive obligations of the government under international environmental standards. The Court relied on UNEP findings about the causes and consequences of the accident, as well as World Health Organization determinations about the health consequences of exposure to sodium cyanide, placing heavy reliance on them in the absence of adequate domestic fact-finding. The Court referred to international standards on best practices for the mining industry and, significantly, quoted extensively from the Stockholm Declaration on the Human Environment, the Rio Declaration on Environment and Development, and the Aarhus Convention. It also included an extract from the ICJ's Gabcikovo-Nagymaros judgment about environmental protection, resolutions of the Parliamentary Assembly, and legal texts of the European Union. In so doing, the European Court declared that the precautionary principle had moved, on the European level, from being a philosophical concept to being a juridical norm with content to be applied. Secondly, the Court recalled the obligation under Stockholm Principle 21 and Rio Principle 14 to prevent significant transboundary harm, noting that both Hungary and Serbia were affected by the mining accident. These international norms, the Court found, should have been applied by the Romanian government.

In Oneryildiz v Turkey, ${ }^{38}$ the ECtHR made reference to several environmental texts, both binding and non-binding, in holding the Turkish government responsible for the loss of life and property resulting from a methane explosion at a waste site. The binding texts deemed relevant were the Lugano Convention on hazardous activities ${ }^{39}$ and the Strasbourg Convention on Protection of the Environment through Criminal Law. ${ }^{40}$ The European Court used the Lugano Convention to define 'dangerous activity' and 'damage' incurring the liability of public authorities. It noted the duty under the

physical security and integrity and the physical environment in which the individual lives. Article 19 of the Constitution establishes 'the right to live in an environment free from contamination'.

35. Inter-Am. Comm. H.R., Report on the Situation of Human Rights in Ecuador, OAS doc. OEA/Ser.L/V/II.96, doc 10 rev. 1, 24 April 1997, Ch VIII, text following n 42 ('Report on Ecuador').

36. Report on Ecuador, ibid, text following n 32.

37. Tatar v Romania (n 30).

38. Oneryildiz v Turkey, App. No. 48939/99 [2004] Eur.Ct. H.R 657 (30 November 2004).

39. Convention on Civil Liability for Damage resulting from Activities Dangerous to the Environment, Lugano, 21 June 1993, ETS No 150.

40. Convention on Protection of the Environment through Criminal Law, Strasbourg, 4 Nov 1998, ETS No 172. The Court noted that the Strasbourg Convention was not in force, but found it 'very much in keeping with the current trend towards harsher penalties for damage to the environment'. 
Strasbourg Convention for authorities to establish criminal offences for loss of life involving the disposal or treatment of hazardous waste.

The Court also made reference in particular to Parliamentary Assembly Resolution 587 (1975) on problems connected with the disposal of urban and industrial waste; Resolution 1087 (1996) on the consequences of the Chernobyl disaster, and Recommendation 1225 (1993) on the management, treatment, recycling and marketing of waste. In addition to Parliamentary Assembly texts, the Court cited the Committee of Ministers Recommendation No. R(96) 12 on the distribution of powers and responsibilities between central authorities and local and regional authorities with regard to the environment.

Like the European Court, the Inter-American institutions have held that the State must comply with and enforce the international agreements to which it is a signatory, whether these are human rights instruments or ones related to environmental protection. Also like the European Court, the IACommHR and IACtHR have held that the provisions of the regional human rights instruments must be interpreted and applied by taking into account 'developments in the field of international human rights law since those instruments were first composed and with due regard to other relevant rules of international law applicable to member states against which complaints of human rights violations are properly lodged'. ${ }^{41}$

The Court and Commission have thus referred to various binding and non-binding instruments in their decisions and country reports. The Commission has explicitly stated that the provisions of ILO Convention No 169, which extensively refer to the environment, 'provide evidence of contemporary international opinion concerning matters relating to indigenous peoples, and therefore that certain provisions are properly considered in interpreting and applying the articles of the American Declaration in the context of indigenous communities' ${ }^{42}$

In its report on human rights in Ecuador, ${ }^{43}$ the Commission noted that the State is party to or has supported a number of instruments 'which recognize the critical connection between the sustenance of human life and the environment', including: the Additional Protocol to the American Convention in the Area of Economic, Social and Cultural Rights (Protocol of San Salvador), ${ }^{44}$ the International Covenant on Civil and Political Rights (ICCPR) ${ }^{45}$ and the International Covenant on Economic Social and Cultural Rights (ICESCR), ${ }^{46}$ the Stockholm Declaration, ${ }^{47}$ the Treaty for Amazonian Cooperation, ${ }^{48}$ the Amazon Declaration, ${ }^{49}$ the World Charter for

41. See Advisory Opinion OC-16/99, The Right to Information on Consular Assistance in the Framework of the Guarantees of the Due Process of Law, 16 IACt.H.R. (Ser A) (1999) [hereinafter Advisory Opinion OC-16/99], para 114 (endorsing an interpretation of international human rights instruments that takes into account developments in the corpus juris gentium of international human rights law over time and in present-day conditions); Report $\mathrm{N}^{\mathrm{o}} 52 / 02$, Case $N^{\circ}$ 11.753, Ramón Martinez Villareal (United States), Annual Report of the IACHR 2002 (Martinez Villareal Case), para 60.

42. Toledo Maya case, n 18, note 123. See similarly Mary and Carrie Dann v United States, Case 11.140, Report No 75/02, Inter-Am. C.H.R., Doc 5 rev. 1 at 860 (2002), paras 127-131.

43. Report on Ecuador (n 35).

44. Protocol of San Salvador (n 24).

45. ICCPR (n 9).

46. ICESCR (1966), 993 UNTS 3.

47. Stockholm Declaration (n 14).

48. Treaty for Amazonian Cooperation, 17 ILM 1045 (1978).

49. Amazon Declaration, 28 ILM 1303 (1989). 
Nature ${ }^{50}$ the Convention on Nature Protection and Wildlife Preservation in the Western Hemisphere, ${ }^{51}$ the Rio Declaration on Environment and Development, ${ }^{52}$ and the Convention on Biological Diversity. ${ }^{53}$ These provided the applicable substantive standards to examine the State's conduct.

In sum, compliance with domestic and international legal norms binding on the State provide a test, and a wholly legitimate one, for determining State responsibility for environmental harm that results in injury to persons' rights under the ECHR.

\section{HUMAN RIGHTS BODIES DO NOT HEAR ENVIRONMENTAL CASES}

In Fadayeva $v$ Russia ${ }^{54}$ the ECtHR noted that because 'no right to nature preservation is as such included among the rights and freedoms guaranteed by the Convention', the adverse effects of environmental pollution must attain a certain minimum level if they are to fall within the scope of Article 8 ECHR.

In Kyrtatos $v$ Greece $e^{55}$ the applicants complained of the noise and lights resulting from tourist development projects near their home. These complaints were not considered sufficiently serious to bring the case within the scope of Article 8 because the applicants had not asserted any deleterious consequences or serious impacts from the alleged pollution. The Court also seemed convinced, probably correctly, that the applicant's main claim concerned 'interference with the conditions of animal life in the swamp'. ${ }^{56}$ In the Court's view, such interference could not constitute an attack on the private or family life of the applicants. The Court referred to the fact that the applicants did not own the protected area. Thus, even though they alleged that the area, which adjoined their property, had lost all its scenic beauty and had changed profoundly in character from a natural habitat for wildlife to a tourist development filled with noise and light, the Court denied the Article 8 claim, holding that:

even assuming that the environment has been severely damaged by the urban development of the area, the applicants have not brought forward any convincing arguments showing that the alleged damage to the birds and other protected species living in the swamp was of such a nature as to directly affect their own rights under Article $8 \mathrm{sec} .1$ of the Convention. It might have been otherwise if, for instance, the environmental deterioration complained of had consisted in the destruction of a forest area in the vicinity of the applicants' house, a situation which could have affected more directly the applicants' own well-being. ${ }^{57}$

The ECtHR has consistently held to the view that nature protection as such is not part of the ECHR's guarantees. If such a guarantee exists under national law, however,

50. World Charter for Nature, GA Res 37/7, UN Doc A/37/51 (1982).

51. Convention on Nature Protection and Wildlife Preservation in the Western Hemisphere, 161 UNTS 229 (1940).

52. Rio Declaration (n 7) Annex I.

53. Convention on Biological Diversity, 31 ILM 818 (1992).

54. Fadayeva v Russia, Apo. 55723/00, 2005/IV Eur. Ct.H.R. 255 (9 June 2005).

55. Kyrtatos v Greece (n 25).

56. Ibid, para 53.

57. Ibid, para 53. The Court does not explain the distinction it makes between a forest and a wetland, provoking the dissenting judge to comment that he was unable to see a major difference between the destruction of a forest and the destruction of the extraordinary swampy environment the applicants had been able to enjoy near their house before the development projects. 
there may be a separate claim for failure to enforce that law, as there was in the Kyrtatos case.

In the Inter-American system, the Commission and Court also have been less willing to hear cases where the environmental issues go beyond immediate human well-being. In 2004, the Commission declared inadmissible a petition from a Panamanian national concerning the Metropolitan Nature Reserve in Panama on the ground that the petition failed to identify individual victims and was overly broad. ${ }^{58}$ The petitioner asserted that the government had violated the right to property of all Panamanians by authorizing construction of a public road through a protected nature reserve. He contended that the status of the nature reserve made it the property of all citizens and not that of the state. After eight years of proceedings, the Commission finally determined that no specific victims were identified and thus the claim was inadmissible. It characterized the case as an actio popularis, while noting the problem this created for the petitioner: 'The Commission does recognize that given the nature of the complaint, the petition could hardly pinpoint a group of victims with particularity since all the citizens of Panama are described as property owners of the Metropolitan Nature Reserve'. ${ }^{59}$ Unfortunately, the Commission's analysis suggests that the more widespread the violations - which can occur in many contexts where environmental harm is the origin of the complaint - the less likely it is that the complaint will be admissible. However, even if the matter concerns public lands or the use of natural resources, there may be procedural guarantees that can be invoked and substantiated. ${ }^{60}$

\section{HUMAN RIGHTS TRIBUNALS FACE CHALLENGES IN FACT-FINDING}

Some of the objections to environmental litigation before human rights tribunals focus on evidentiary issues, including the evaluation of risk, causality and proof of harm, as well as the lack of scientific expertise of those sitting on the tribunals. In fact, these issues have not been particularly difficult in many cases, because the record of domestic fact-finding has sufficiently revealed the risks entailed or the harm produced by the challenged activity.

More generally, problems of fact-finding are not unique to environmental cases: human rights tribunals generally are not well designed for fact-finding in the absence of a domestic record. Cases are filed often years after the events in question and there

58. Petition 11.533 (Panama), Report No 88/03, Annual Report 2004.

59. Ibid, para 34.

60. For further commentary on this case see R Pavoni, 'Environmental Jurisprudence of the European and Inter-American Courts of Human Rights: Comparative Insights' in B Boer (ed), Environmental Law Dimensions of Human Rights (OUP 2015) 94 and 98. In the case of Claude Reyes et al. v Chile, judgment of Sept. 19, 2005, IACtHR Ser C, No 151, the IACtHR found violations of the right to information and the right to judicial remedies after the Chilean Committee on Foreign Investment failed to release information about a deforestation project the petitioners wanted to evaluate and the domestic courts refused to admit the subsequent case against the state. The Court cited a wide range of documents, including not only OAS declarations on democratic governance and its own jurisprudence, but also Principle 10 of the Rio Declaration on Environment and Development, resolutions of the Committee of Ministers and Parliamentary Assembly of the Council of Europe, and the Aarhus Convention on Information, Public Participation and Access to Justice. The Court directed the government to devise the means to ensure access to information and provide the information sought by the applicants. 
may be little if any reliable record due to the lack of domestic proceedings. The problem of 'duelling narratives' between the applicants and the respondent state is a common one. In environmental cases, it is sometimes asserted that the problems are exacerbated by technical scientific issues, but arguably this is no more difficult than determining whether or not an individual was killed in self-defence or arbitrarily executed by the police, or whether an individual was forcibly disappeared or fled to join an uprising, as the State asserts.

Assessing risk has been an important issue in litigating many human rights cases concerning the environment. Some human rights procedures limit standing to 'victims' of violations, and there must be a sufficient threat for the applicants or petitioners to qualify as a victim. ${ }^{61}$ In this respect and on the merits, the precautionary principle has begun to play a role in bringing more risks within the ambit of human rights litigation. The Taşkin case, for example, concerned the risk involved in the use of cyanide in gold extraction. The ECtHR first found Article 8 ECHR to be applicable 'where the dangerous effects of an activity to which the individuals are likely to be exposed have been determined as part of an environmental impact assessment procedure in such a way as to establish a sufficiently close link with private and family life for the purposes of Article 8 of the Convention'. ${ }^{62}$ The Court went on to find a violation of Article 8, based on the evidence of the domestic court judgments. The Court held that 'in view of' the conclusion of the domestic court on the absence of a public interest in allowing the gold mine, it did not need to examine the case from the perspective of the normally wide margin of appreciation afforded governments in environmental matters.

In Fadayeva, ${ }^{63}$ similarly, the findings of domestic and international agencies with expertise in pollution assisted the ECtHR. A government decree had recited statistics on the increases in respiratory and blood diseases linked to air pollution, as well as the increased number of deaths from cancer. ${ }^{64}$ The government had also determined by legislation the safe levels of various polluting substances, many of which were exceeded in the security zone where the applicant lived. The mayor of the city said that the steel plant was responsible for more than 95 per cent of industrial emissions into the town's air, ${ }^{65}$ while a State Report on the Environment indicated that the plant in question was the largest contributor to air pollution of all metallurgical plants in Russia. These two statements reduced concerns about causality. In the end, both parties agreed that the applicant's place of residence was affected by industrial pollution caused by the steel plant, but they disagreed over the degree and effects of the pollution.

The main problem for the applicant was linking the pollution to the deterioration of her health - in other words, the problem of causality. Her medical records indicated

61. See Bordes and Temeharo v France, Comm. No. 645/1995, CCPR/C/57/D/645/1995, 30 July 1996. The risk of harm from nuclear radiation due to nuclear testing by France in the South Pacific was deemed too remote for the victims to qualify as victims.

62. Taşkin (n 28) para 113 (emphasis added).

63. See also Ledyayeva, Dobrokhotova, Zolotareva and Romashina v Russia, nos 53157/99, $53247 / 99,53695 / 00$ and 56850/00, judgment of 26 Oct. 2006, also involving the same steel plant built during the Soviet era.

64. Russia's Constitution, Art 42 guarantees as follows: 'Everyone has the right to a favorable environment, to reliable information about its state, and to compensation for damage caused to his health or property by ecological disease'. The provision was not invoked in the case.

65. The Court noted that this made the case different from and more easily definable than other air pollution cases where multiple minor sources cumulate to produce the problem. 
problems but did not attribute them to any specific causes. The doctors stated, however, that her problems would be exacerbated by working in conditions of vibration, toxic pollution and in an unfavourable climate. ${ }^{66}$ The applicant also submitted an expert report, ${ }^{67}$ which linked the plant specifically to increased adverse health conditions of persons residing nearby. The EctHR found that the medical evidence did not establish a causal link between the pollution at her residence and her illnesses, but accepted that the evidence, including submissions by the government, was clear about the unsafe excessive pollution around her home. The Court also made reference to the expert report and the findings of the domestic courts. The Court noted that Russian legislation defined the maximum permissible concentrations as 'safe concentrations of toxic elements'. Therefore, exceeding these limits produced a presumption of unsafe conditions that were potentially harmful to the health and well-being of those exposed to it. This presumption, together with the evidence submitted, led the ECtHR to conclude that the applicant's health had deteriorated as a result of her prolonged exposure to the industrial emissions from the steel plant. Alternatively, even if that harm could not be quantified, the pollution 'inevitably made the applicant more vulnerable to various illnesses' and affected her quality of life at home. ${ }^{68}$

The EctHR's analysis raises the question of what evidence is sufficient to raise the presumption the Court creates in the Fadayeva case. It should not be limited to domestic legislative or administrative findings, because as Zander $v$ Sweden indicates, safe levels may be changed to accommodate economic interests without necessarily being based on sound science. The World Health Organization (WHO) and other scientific bodies have determined through epidemiological studies what constitutes safe levels of concentration of toxic, carcinogenic, mutagenic and other hazardous substances. ${ }^{69}$ Reliable evidence of such studies can and should be introduced to demonstrate presumed harm when such levels are exceeded, even if local legislation permits higher concentrations. A petition admitted by the IACommHR relies on such WHO standards to assert that the average sulphur dioxide levels from a metallurgical complex are detrimental to the lives and health of the nearby community in Peru. ${ }^{70} \mathrm{In}$ the Tatar case, the EctHR relied on UNEP findings about the causes and consequences of the accident, as well as on WHO determinations about the health consequences of exposure to sodium cyanide, placing heavy reliance on them in the absence of adequate domestic fact-finding.

The ECtHR's standard of proof is high ${ }^{71}$ but flexible and takes into account the fact that governments often are the sole repository of relevant evidence. Indeed, in

66. Fadayeva $v$ Russian (n 54) para 45.

67. The court made it a point to recite the qualifications of the expert when discussing the report. See ibid, para $46 \mathrm{n} 1$.

68. Ibid, para 88.

69. The WHO has developed guidelines for safe and acceptable water quality and quantity: World Health Organization, 'Guidelines for Drinking Water Quality' (3rd edn, WHO 2004). Independent surveillance of water quality, quantity, accessibility, affordability and long-term availability are part of the WHO framework.

70. Inter-American Commission on Human Rights, Report No. 76/09, Case 12.718, Community of La Oroya, Peru, admissibility decision of 5 August 2009, OAS/Ser/L/V/II.135, doc. 23. 71. It has long demanded 'proof beyond reasonable doubt' (Fadayeva (n 54) para 79) which can follow from the coexistence of sufficiently strong, clear and concordant inferences or of similar unrebutted presumptions of fact. 
the case of Fägerskiöld $v$ Sweden ${ }^{72}$ the Court cited WHO guidelines ${ }^{73}$ on noise pollution in rejecting the admissibility of an application concerning wind turbines constructed and operating near the applicants' property. The Court noted that the WHO guidelines were set at the level of the lowest adverse health effect associated with noise exposure. The Court also referred to even lower maximum levels adopted by most European countries. Applying these standards to the noise level tests submitted in the case, the Court found that the levels of noise did not exceed the WHO guidelines, and were minimally above the recommended maximum level in Sweden. Therefore the environmental nuisance could not be found to reach the level of constituting severe environmental pollution.

In a subsequent case involving the same Russian steel mill as was the subject of the Fadayeva judgment, the EctHR explained further:

There is no doubt that serious industrial pollution negatively affects public health in general. However, it is often impossible to quantify its effects in each individual case, and distinguish them from the influence of other relevant factors, such as age, profession, etc. The same concerns possible worsening of the quality of life caused by the industrial pollution. The 'quality of life' is a very subjective characteristic which hardly lends itself to a precise definition. Therefore, taking into consideration the evidentiary difficulties involved, the Court has no other choice than to repose trust primarily, although not exclusively, in the findings of the domestic courts and other competent authorities in establishing factual circumstances of the case. ... However, the Court cannot rely blindly on the decisions of the domestic authorities, especially when they are obviously inconsistent or contradict each other. In such [a] situation it has to assess the evidence in its entirety. ${ }^{74}$

Human rights tribunals, indeed all tribunals, face evidentiary problems in attributing cause and effects to environmental harm. So do legislatures and administrative agencies; this problem is part of the rationale leading to the development of the precautionary principle. Unfortunately, the need for expert testimony and scientific analyses sometimes leads to the problem of 'duelling experts' who testify in a contradictory manner about whether there is pollution or other environmental degradation, what the cause of that degradation might be, and whether or not any harm to the applicants could be attributable to the (disputed) harm. Contradictory environmental impact assessments can prove a serious barrier to reaching a sound conclusion, ${ }^{75}$ but the

72. Fägerskiöld v Sweden, no. 37664/04 (admissibility), 26 Feb. 2008.

73. World Health Organization, 'Guidelines for Community Noise' (WHO 1999).

74. Ledyayeva (n 63) para 90.

75. IACHR, PM 260-07 - Communities of the Maya People (Sipakepense and Mam) of the Sipacapa and San Miguel Ixtahuacán Municipalities in the Department of San Marcos, Guatemala. On May 20, 2010, the IACHR granted precautionary measures for the members of 18 Guatemalan indigenous communities. The petitioners alleged that a mining concession was issued and mining began without the prior, complete, free and informed consultation with the affected communities. The petitioners also maintained that the mining produced grave consequences for the life, personal integrity, environment and property of the affected people, polluting the only sources of water for consumption and subsistence activities. The Inter-American Commission asked the State of Guatemala to suspend the Marlin I mine and to implement effective measures to prevent environmental contamination, until such time as the Inter-American Commission on Human Rights adopted a decision on the merits. On December 7, 2011, after examining additional information submitted by the State and the petitioners, the IACHR notified its decision to modify these precautionary measures, and requested the State 
2014 ICJ judgment in the Whaling case ${ }^{76}$ gives useful advice to litigants and judges on hearing and assessing purported scientific evidence.

\section{CONCLUSIONS}

The judicial function is often centred on the interpretation and application of vague legal guarantees. Tribunals which have customarily dealt with human rights issues are capable of bringing content to rights linked to environmental conditions and of developing the corresponding State obligations. Yet, the limits of human rights procedures should be kept in mind. Litigation is often prolonged and may not serve to halt or to mitigate environmental harm in time to prevent irreversible damage. Indeed, in the ECtHR at least, the remedies afforded generally do not directly ensure protection for, or remediation of, the environment. Thus, Ms Fadayeva was given compensation for the injury to her health, but the polluting steel mill continues to operate. Although in theory, the IACtHR could order specific action to be taken to stop environmental harm, thus far it has not done so except in cases relating to the collective property rights of indigenous peoples. ${ }^{77}$

Moreover, judges are often very deferential to political decisions about the desirability of economic activities and the level of environmental protection desired for the affected society. The question judges must face is determining when domestic laws and policies are so deficient that they fall foul of human rights guarantees. Domestic courts as well as human rights tribunals must confront this issue. In Clean Air Foundation Limited \& Gordon David Oldham v The Government of the Hong Kong Special Administrative Region, ${ }^{78}$ the applicants sought judicial review of the authorities' alleged failure to take the necessary measures to combat air pollution. The applicants contended that Hong Kong's air is so polluted that it is poisoning the people who live there, shortening their lives in breach of the Bill of Rights and of various international covenants which have been extended to Hong Kong, in particular the right to health as set forth in Article 12 of the ICESCR. ${ }^{79}$ The Court accepted that Article 12 imposes a duty on state authorities to combat

of Guatemala to adopt the necessary measures to ensure that all beneficiary members of the 18 Mayan communities have access to potable water appropriate for human consumption and household use, as well as for irrigation purposes. Specifically, the IACHR requested the State to take the necessary measures, in order that the 18 beneficiary communities' water resources are not contaminated by mining activities. The information on this matter is available at <www.iachr.org/en/iachr/decisions/precautionary.asp $>$.

76. Whaling in the Antarctic (Australia v Japan: New Zealand Intervening), ICJ Rep. 2014 (31 March).

77. See eg Case of the Saramaka People v Suriname, judgment of 28 Nov 2007; Indigenous Community Sawhoyamaxa (n 18); Mayagna (Sumo) Awas Tingni Community (n 18); Indigenous Community Yakye Axa v Paraguay (n 18); Sarayaku v Ecuador (n 18).

78. CAL 35/2007, Court of First Instance, Constitutional and Administrative Law List, No 35 OF 2007 Judgment of 26 July 2007.

79. ICESCR (n 46), Article 12 reads:

1. The States Parties to the present Covenant recognize the right of everyone to the enjoyment of the highest attainable standard of physical and mental health.

2. The steps to be taken by the States Parties to the present Covenant to achieve the full realization of this right shall include those necessary for: ...

(b) The improvement of all aspects of environmental and industrial hygiene.... 
air pollution, even if this cannot be an absolute duty to ensure with immediate effect the end of all pollution. Nonetheless, the Court held that the issue was one of policy, not law. It stated:

A policy may, of course, be unlawful. But because a policy is considered to be unwise, short-sighted or retrogressive does not make it unlawful. It has long been accepted that policy is a matter for policy-makers and that to interfere with the lawful discretion given to policy-makers would amount to an abuse of the supervisory jurisdiction vested in the courts. $^{80}$

The applicants submitted that they did not seek to review the wisdom of government's policies in respect of air pollution, but rather to determine whether the Government had met its obligations in law. The Court was unable to agree, finding that the real issues in the case were not issues of legality and did not go to the Government acting outside of its powers. Instead, they went to the question of why the Government had not chosen to pursue certain policies.

Adjudicating cases under broadly-worded standards is not new for judges, however, nor is it uncommon for them to be faced with adjudicating highly technical matters. Courts must regularly, and on a case-by-case basis, define what constitutes 'reasonable', 'fair', or 'equitable' conduct. With the adoption of constitutional environmental rights provisions, many courts have taken the view that such enactments serve to place environmental protection in a position superior to ordinary legislation. Over time, courts tend to create a balancing test to avoid too readily undoing the deliberative decisions reached by the political branches of government.

Even under deferential standards of review, human rights tribunals may find that the procedures followed or substance of decisions reached by governments fail to comply with applicable international human rights standards. Where such judgments involve major development projects supported by important economic interests, the backlash may be considerable. Experience in some of the regional human rights bodies where there has been deliberate non-compliance with requests for precautionary measures or with judgments of the court indicate the political problem in deciding cases where human rights violations stem from economic activities that disproportionately harm one sector of society.

The environmental aspects of human rights law are not about stopping all human activities, but about recognizing that many activities utilize scarce resources and produce emissions and waste that inevitably have individualized and cumulative impacts not only on nature, but on human beings. These impacts have to be considered, measured and monitored, with the result that some activities will be limited or prohibited. Environmental science helps determine the causal links between the activities and the impacts, giving courts a set of data upon which to base decisions about whether or not a proper balance of interests has been obtained, one which ensures an equitable outcome and minimizes the risk of harm to the environment and to human rights.

80. Ibid. 